\title{
Chapter 1 \\ World Jewish Congress Activity in the United States during World War II
}

\section{The World Jewish Congress and Reports of the Holocaust of European Jewry}

In justifying the founding of the organization to the broad public, the "World Jewish Congress leadership cited the need for Jewish unity in circumstances of extreme crisis. Yet upon perusing speeches delivered at intimate forums and confidential documents written by WJC leaders in the latter half of the 1930s and the early 1940s, a number of additional reasons leading to the decision to establish the organization emerge. The WJC leadership's clandestine activity during the war years is quite different from its overt rhetoric; from it we learn that an additional motive for founding the Congress was the desire of the elite to maintain control over Jewish political activity rather than "abandoning" it to those liable to harm the interests of American Jewry.

Whereas broad sections of the American Jewish public appeared eager to exert overt and intensive pressure on the United States administration, the initiators of the WJC feared that such direct mass activity might adversely influence the status and interests of American Jews, and sought to respond to the public's demand for "ethnic politics" in a manner that would satisfy, but not harm it.

The intensive correspondence among WJC leaders in the United States reveals their views on the political and public means whereby they hoped to persuade the wielders of political power in Europe and the United States to take action on behalf of European Jews, while protecting the interests of the American Jewish public. They believed that it would be dangerous to allow those unfamiliar with the ways of world politics to lead the Jewish struggle since they were apt to damage these interests. They thus opposed, for example, the public campaign waged by American Jews in 1938 for the imposition of an American embargo on trade with Romania in the wake of the deteriorating situation of the Jews in that country. This had come about because of the anti-Jewish policy pursued by the Goga-Cuza regime, which took the form of discriminatory legislation, rescinding the citizenship of hundreds of thousands of Romanian Jews, and depriving them of their livelihoods in villages and cities. ${ }^{66}$ Wise and Goldmann were aware of

66 Jean Encel, The Annals of the Holocaust: Romania [in Hebrew] (Jerusalem, 2002), vol. 1, 5182. 
the plight of Romania's Jews, but felt that the call for an embargo was illogical and irresponsible, since those waging the campaign were largely ignorant of the workings of international politics and knew little about the facts on the ground. They were unaware, for instance, of the small volume of Romanian imports to the United States, which meant that the embargo would not constitute a substantial threat to the Romanian regime, and that calls for its imposition were seriously jeopardizing efforts to reach an understanding with the Romanian government aimed at improving the conditions of its Jewish citizens. ${ }^{67}$ Wise was convinced that the League of Nations was the appropriate forum in which to engage in activity on behalf of Romanian Jewry. Furthermore, he believed that this activity should focus on applying international political pressure on the Romanian regime through individual diplomatic meetings with its leaders, such as Nahum Goldmann's encounter with the Romanian foreign minister, which he would describe in a report to Wise in September of that year. ${ }^{68}$

Several factors exacerbated the dilemma facing the WJC functionaries regarding the appropriate approach to use on behalf of European Jews: the outbreak of World War II, the United States' entry to the war, and reports of the murder of European Jews by the Nazis. The actions of the WJC leaders reflected the fact that they possessed reliable and current information on the murder of European Jewry. The most well-known evidence of this is the telegram dispatched by Gerhart M. Riegner, director of the Congress's Geneva bureau, to Stephen Wise in New York. The message contained dramatic information, furnished by the German industrialist Eduard Schulte, about Hitler's decision to exterminate European Jewry in its entirety using industrialized killing machines operated by gas. The telegram reached New York via a circuitous route on August 28, 1942, twenty days after it had been dispatched. The communication was dubbed "the Riegner Telegram" and the information it contained is considered to be the first reliable source of information on the Final Solution. Upon receipt of the telegram, Wise immediately contacted the U.S. State Department to convey the terrible news and request authorization to make it public. The response from Under-Secretary of State Sumner Welles was to ask Wise to delay publication be until the information was verified. Wise agreed-a decision that would later draw fierce criticism from

67 Wise's letter to Goldmann, January 18, 1938, CZA, Z-6/2765.

68 On the WJC leadership's prior activity on behalf of Romanian Jewry, see Schwarzbart, 25 Years, 9-10; Encel, Annals of the Romanian Holocaust, 69-74. On Goldmann's meeting with the Romanian foreign minister, see Goldmann's letter to Wise, September 22, 1938, CZA, Z-6/2765. Wise also proceeded with great caution with regard to efforts to impose an embargo on German products. See Urofsky, Wise, 297-298. On the Holocaust of Romanian Jews, see Loanid Radu, The Holocaust in Romania - The Destruction of Jews and Gypsies Under the Antonescu Regime, 1940-1944 (Chicago, 2000). 
scholars and non-academics alike. Authorization from the State Department was not received until November 24, 1942, at which time Wise announced to the press that the Nazis intended to annihilate European Jewry and that two million Jews had already been murdered. ${ }^{69}$

While Riegner's telegram is widely cited, it is but one example of evidence obtained through an elaborate information-gathering network that the WJC operated in neutral European countries. ${ }^{70}$ The WJC leadership not only had the foresight to continue running its offices in the neutral countries, they also developed clandestine modes of operation more quickly than did other Jewish organizations, enabling them to obtain information about the fate of the Jews in Nazi-occupied countries in real time. The heads of the Congress were thus able to gain knowledge on topics ranging from information on individual Jews, to the layout of the Treblinka extermination camp, to the situation of Jewish children in hiding in France and Belgium. The reports and testimonies that reached the offices of the WJC during 1942 and 1943 reveal that the organization's leaders were indeed aware of the plight of European Jewry. Therefore, we can stipulate that efforts by the WJC in the United States to rescue Jews during the Holocaust should be examined in light of the extensive information at their disposal.

Specific information on current events in Poland also reached WJC offices in the United States and in Europe, and was collated into a comprehensive report. The authors of the report, submitted in October 1942, stressed that part of the information had arrived directly from the Warsaw Ghetto, while other parts had been sent by a circuitous route, and in some cases were based on oral testimony alone. ${ }^{71}$ Nevertheless, since the numerous sources provided similar or identical information, they were assumed to be reliable. Reporting in their introduction that hundreds of thousands of Jews had been murdered in Warsaw, the authors comment that "The horror defies belief." Other reports told of the systematic gassing of many Warsaw Jews who were removed from the ghetto and transported to an unknown location. Upon assembling the testimonies, the report's authors concluded that the Germans' campaign of murder of the Jews had commenced with the Jews from Western and Central Europe to work camps in the East. The majority of those arriving in the camps soon died of hunger and disease. ${ }^{72}$

69 Jonathan Sarna, American Judaism [in Hebrew] (Jerusalem, 2005), 252-253. The matter of the delayed revelation is discussed here in the chapter on the topic of rescue.

70 See, for example, Friling, Ben Gurion, 84-85.

71 Report from the Congress office in Geneva titled "The Situation of the Jews in the General Government," October 8, 1942, AJA, 361 H287/12.

72 Ibid. 
The report went on to describe the deportation and murder of Jews in various locations in Poland, as well as the reaction of the non-Jewish public to the Nazis' treatment of the Jews. Anonymous sources within the Polish government-in-exile reported that in many areas the Poles had participated in massacres of Jews, termed pogroms by the report's authors. In Warsaw, however, the city's Polish population had not taken part in the anti-Jewish activity for the simple reason that the total separation of the ghetto prevented them from participating in the massacres. $^{73}$

Additional testimony regarding events in occupied Europe reached the Congress office in Geneva shortly after the Riegner telegram was dispatched. This information was passed on to a Congress functionary, the jurist Prof. Paul Guggenheim, by a senior official in the Swiss administration, whose name had been deleted for obvious reasons. ${ }^{74}$ The witness had learned from key figures in the Nazi regime of an order by Hitler to exterminate (this term appears in the original testimony!) all the Jews of Germany and occupied Europe by the end of December 1942. The informer related that S.S. Commander Himmler and Governor of Poland Frank opposed the immediate implementation of the order. This did not stem from humanitarian considerations, but rather from a desire to continue to exploit the Jews for forced labor. Professor Guggenheim emphasized that the information pertaining to the extermination order was supported by two further sources: a German Foreign Ministry official posted in Bern, and an official in the German War Ministry. Additional information was passed to Guggenheim by a Swiss national resident in Belgrade. This source related that German officials with whom he was in contact had informed him that the Jewish issue was of the utmost importance to the Nazi leadership and advised him to refrain from any involvement with the matter in light of his prior intervention on behalf of Jews. This Swiss national told of information he had received suggesting that no Jews remained in Serbia. Guggenheim stressed that the information he had obtained lent support to the facts contained in Riegner's telegram. ${ }^{75}$

Jewish refugees who had managed to escape from Nazi-occupied countries supplied important information about events in occupied Europe. The WJC office in Switzerland actively sought to locate refugees who had arrived there. The office assisted them financially and handled bureaucratic issues in order to prevent the

73 The report includes a comprehensive survey of information pertaining to Jewish issues appearing in the German press and in newspapers in the occupied lands. See Geneva Report, October 8, 1942, AJA, $361 \mathrm{H} 28 / 12$.

74 The information is contained in Guggenheim's official testimony to the American consul in Geneva, October 29, 1942, AJA, 361 A8/11.

75 Guggenheim, ibid. 
refugees' deportation from Switzerland; meanwhile the Congress functionaries interrogated them thoroughly. The full importance of this process emerges in light of the fact that the Swiss authorities made no effort to debrief these Jewish refugees, totally ignoring the information they conveyed. A Jewish refugee of Polish origin residing in Brussels, who eventually moved to Switzerland, told of his arrest in Belgium. ${ }^{76}$ Those arrested included women and children, some of whom had received no prior warning. After the arrest the men were separated from the women and children and taken to an unknown destination. The man then told of the horrors of being transported in crowded cattle trucks to the Russian front and put to work in the mines and on fortifications there in conditions of constant hunger. The daily food ration consisted mainly of 225 grams of bread. When one of the German chauffeurs fell ill, the informant was appointed to act as chauffeur to a German officer, with whom he developed a cordial relationship. The officers' two brothers had been killed on the Russian front and he opposed Nazi policy toward the Jews. The officer told him that Jews who were unable to work were either shot dead or murdered by having poison added to their food. The officer had given the survivor an appropriate work permit and clothes and put him on a train to Paris; from there he had escaped to the Vichy-controlled territory and on to Switzerland. The interviewers noted in the document that the 33-year-old informant was highly reliable and that his narrative matched the information conveyed by other refugees. ${ }^{77}$

Further information about the fate of Poland's Jews arrived in a telegram sent from the WJC's London office to New York. ${ }^{78}$ Unnamed sources told of the deportations from the Warsaw Ghetto, noting that ten thousand Jews were being sent to their deaths every day. While it does not mention mass murder by means of gas, the cable conveys information on Sobibor, Belzec, and Treblinka-all defined as death camps where mass murders of men, women and children take place and their bodies buried in mass communal graves. The telegram concludes with a heart-rending cry, "Believe the unbelievable!"79

Additional testimonies reached the WJC office early in 1943, assembled in a comprehensive report that primarily addressed the Treblinka extermination camp and the Warsaw Ghetto. Of Treblinka the authors wrote: "Treblinka, the concentration camp which absorbed the Warsaw Ghetto dwellers for all eternity will

76 Report by the Congress office in Geneva titled "Report of a Jewish Refugee,” November 19, 1942, AJA, $361 \mathrm{H} 287 / 10$. The refugee delivered his testimony on October 10, 1942, but it reached New York only on November 19.

77 Ibid.

78 See Telegram, December 1, 1942, AJA, 361 A9/20.

79 Ibid. 
probably be the greatest Jewish mass grave in our history." 80 The information on Treblinka and Warsaw Ghetto was delivered in three separate reports dispatched by official sources close to the Polish government-in-exile. While WJC officials believed that these were entirely reliable non-Jewish sources, they nevertheless maintained that the reports were slightly biased since their authors were gentiles. They felt, for example, that the emphasis placed on the fact that the Jews had not resisted the German actions over a prolonged period stemmed from the wish to absolve the Polish public of blame for cooperation with the Germans, intimating, in other words, that since the Jews themselves had not resisted, Warsaw's Polish residents could hardly have been expected to actively oppose the atrocities. ${ }^{81}$

The authors of the summary document, distributed among a wider group of WJC officials, noted that it was based on the reports of Jewish as well as non-Jewish witnesses, some of whom were still located in Nazi-occupied countries. The testimonies of the witnesses were cited without alteration, apart from essential deletions to preserve their anonymity. The authors mentioned that they had refrained from including the witnesses' conjectures or testimonies that were not substantiated by several sources. ${ }^{82}$

80 Memorandum to the top leadership of the WJC, including Wise, Goldmann and Tartakower, regarding information on events in Poland, June 26, 1943, AJA, 361 B1/5 (emphasis in the original). 81 Ibid.

82 Document on Treblinka and the Warsaw Ghetto, presented by the World Jewish Congress and a delegation of Polish Jewry, September 1943 (no precise date or author specified), AJA, 361 H294/2. Shortly prior to the publication of the report, the Congress leaders met with Jan Karski, an emissary of the Polish underground who had visited the Warsaw Ghetto and one of the classification, or transit, camps linked to the Belzec extermination camp, and who had revealed to the Allies and to the WJC leadership what was occurring there. The report does not rely on the information conveyed by Karski, since it addresses the Treblinka extermination camp and the final stages of the existence of Warsaw Ghetto, which were not topics addressed by Karski. On the Congress leaders' meeting with Karski, see minutes of meeting, August 9, 1943, AJA, 361 H287/12. Yitzhak Arad has written that the Polish underground knew what was happening at Treblinka and conveyed information on the camp to the Polish government in exile in London. One may assume that part of the information in the Congress report is based on the material transmitted from occupied Poland to the Polish government in exile. The Congress maintained close links to the Polish government in exile and it is therefore reasonable to assume that the material was conveyed to the WJC rather than to some other Jewish organization. On the reports by the Polish underground on Treblinka, see Yitzhak Arad, Belzec, Sobibor, Treblinka: The Operation Reinhard Death Camps (Bloomington and Indianapolis, 1987), 349-359. Arad's descriptions of Treblinka accord with those in the Congress's report. See Arad, Treblinka, 81-113. On the links between the WJC and the Polish government in exile, see, for example, Minutes of a Meeting of European Congress functionaries, including Goldmann and Riegner, classified top secret, December 6, 1939, AJA, 361 A7/1. 
The first section of the document provides detailed information about the Treblinka extermination camp. The witnesses told of its location in the vicinity of the village of Treblinka, adjacent to the railway station. The camp began operation as a detention center for Poles; the camp known as Treblinka B was erected later. Construction ended in April 1942 when the building of what the witnesses dubbed "Death Chamber No. 1" was completed..$^{83}$

A detailed map describing the security measures and the electrified fence was appended to the document. Particular attention was paid to the description of death chambers Nos. 1 and 2, including detailed information on building materials, dimensions, and technical specifications regarding their means of operation. The witnesses related that a small team of Ukrainians and SS men, led by an SS officer named Saur who held a rank equivalent to major, operated the death chambers. This was followed by an account of the camp's daily routine, including a description of the accommodation blocks housing the Jews who worked in the camp, and an explanation of the role of the kapos (prisoners in Nazi concentration camps assigned by the SS to supervise forced labor and/or carry out administrative tasks). According to the report's authors, the testimonies indicated that the majority of Jews who operated the death machine in Treblinka failed to survive beyond two weeks, succumbing to hunger and the cruel treatment meted out to them. ${ }^{84}$

A large part of the report was devoted to a description of the process of murder, from the arrival of the transports, through entry to the gas chambers, to the burial of the corpses. The entire process was termed "The Tragedy of Treblinka." The witnesses reported that two transports arrived daily, one in the morning and another toward evening, but on some days additional transports would arrive. The separation of the men from the women and children was described, as was the subterfuge by which the Germans sought to conceal the true function of the gas chambers from the victims. The document provides detailed data, from a description of the signs welcoming those arriving from the Warsaw Ghetto, to the precise manner in which the corpses were burned. The information contained in the report is extremely comprehensive and corresponds to what is known today. One may thus assume that the details are reliable and are based on first-hand experience. $^{85}$

The second section of the report addresses the Warsaw Ghetto. The testimonies tell of its establishment in October 1940 and of the means of terror employed to herd the Jews inside. Based on the collection and comparison of a variety of

83 Report, September 1943.

84 Ibid.

85 Ibid. 
data, the authors concluded that the ghetto housed between 450,000 and half a million Jews prior to the deportations. A Jew who succeeded in escaping from the ghetto with the assistance of a Polish friend told of the atmosphere of fear and terror in the ghetto on the eve of the deportations and as they were taking place. The document is replete with details of everyday life: the price of bread, the various plants that employed Jews and the number of workers in each of them, the food given to the workers, the number of those who willingly reported for transportation as opposed to those who went into hiding, tables recording the daily number of deportees, and information on the numbers of those who perished of famine and disease. ${ }^{86}$

In contrast to the detailed descriptions of daily life in the ghetto, the document provides little information about acts of resistance. It is possible that the witnesses and sources available to the document's authors had not actively participated in the fighting and did not belong to resistance organizations.

The resistance that began in January 1943 and the subsequent German offensive on April 19, 1943, are portrayed from the perspective of a bystander who is impressed by the manner in which the Germans were stopped in the initial stages of the uprising and goes on to relate how the resistance petered out beginning on April 23 as the Germans began to burn down the ghetto. The authors surmise that only a small number of ghetto residents had survived by escaping to the Polish section of Warsaw. The rest were either killed during the course of the German offensive, shot by the Germans in the ghetto, or dispatched to the death camps. ${ }^{87}$

The information accumulated by the WJC office during 1942 and the first half of 1943 pertaining to the process of murder of European Jewry was instrumental in making Jewish leaders around the world, the heads of the Zionist movement, and Allied leaders aware of the fact that the Germans were energetically and systematically exterminating the Jews of Europe..$^{88}$, as well as graphic descriptions of the killing process: the unbearable crowding in the cattle trucks used to deport the Jews, testimonies on the miniscule portions of food allocated to the Jewish

86 Ibid. The information in the report on Warsaw Ghetto likewise accords with the findings of scholars in later years. On Warsaw Ghetto, see Israel Guttman, senior editor, Encyclopedia of the Holocaust [in Hebrew], vol. 2 (Tel Aviv, 1990), (459-480).

87 Report, September 1943.

88 Stephen Wise conveyed the information about the process of extermination to other Jewish leaders in the United States and to various arms of the administration, including President Roosevelt. See Urofsky, Wise, 321-323. The WJC convened press conferences and initiated radio broadcasts in the United States and Britain on the topic of the extermination of European Jews and also organized mass demonstrations, particularly in New York. See Kubowizki, World Jewish History, 160-164. On efforts to arrange a meeting with the Under Secretary of State in the wake of the information from Europe, see Memorandum of November 19, 1942, AJA, 361 H287/10. 
laborers, and descriptions of the manner in which the corpses were disposed of to ensure maximum efficiency.

Tuvia Friling has addressed the "leap of consciousness" required of David Ben Gurion, chairman of the Jewish Agency Executive, and of other Jewish leaders in order to internalize and appreciate what was happening in Europe, even after they were exposed to the initial reports on the process of extermination. ${ }^{89}$ The information provided by the institutions of the WJC created a factual base that enabled Congress leadership and Jewish leaders in general to make that leap of consciousness and comprehend fully and accurately what was occurring in Europe, and would continue to occur there throughout the German occupation. ${ }^{90}$ WJC documentation demonstrates the enormous impact of the information on its leaders' perception of the events in Europe. The Congress leadership had been aware of the process of ghettoization, the famine and the mass killing of Jews in Eastern Europe (pogroms), prior to receiving the information from Europe. ${ }^{91}$ Even after the initial reports of the final solution arrived, the modes of its precise implementation remained unclear. The reports told of increasing numbers of Warsaw Jews who had been transported to an unknown destination, and whose fate remained unknown. ${ }^{92}$ Receipt of the detailed descriptions of the killing process in the Treblinka extermination camp completely altered the WJC leadership's understanding of events in Europe. The importance of the information collected by WJC offices in Europe was not lost on scholars; nevertheless, one can only appreciate the full significance of this information by perusing the volumes of documents pertaining to the issue, which are preserved in the WJC archive and are cited here.

The attempts on the part of the WJC team of authors to find the appropriate words to describe the extermination process reveal something of the challenge they faced in their efforts to comprehend the information that flowed from Europe. They sought to impress upon their readers that what was happening could not be adequately understood in the same context as previous instances of Jewish persecution throughout European history. Guggenheim was able to write about the Germans' intention to exterminate the Jews of Europe, but the authors of these documents found it all but impossible to portray the events of which they were

89 Friling, Ben Gurion, 96-97.

90 For his thoughts on Ben Gurion's exposure to the Riegner telegram, see ibid, 84-6. In the following chapters we trace how some of the Congress leaders' assessments of the scope of the extermination process and of what lay in store for the Jews of Europe were submitted to the Zionist leadership and to bodies in Palestine. See letter from Nahum Goldmann to Yitzhak Gruenbaum, April 5, 1943, CZA Z-6/2755.

91 See Report on the Condition of European Jewry prepared by the Congress's Institute of Jewish Affairs, July 1, 1942, AJA, 361 A1/7.

92 Classified memorandum prepared by Jacob Robinson, January 25, 1943, AJA, 361 D104/6. 
now aware. ${ }^{93}$ Thus, in a telegram describing what was happening to the Jews of Poland, they simply characterized the events of 1942 as "unbelievable!" Similar terminology was employed in other documents reporting the murder of Polish Jews. ${ }^{94}$ The events in Warsaw Ghetto were described as "tragic," while further acts of mass murder in other locations in Poland were designated as "pogroms." A subsequent report defines the German actions as a program designed to exterminate the majority of European Jewry. ${ }^{95}$ The first-and only-reference to the term Holocaust in WJC documents of 1942-43 was made by Stephen Wise in a speech delivered to the American Jewish Convention in New York in August 1943. ${ }^{96}$ On this occasion the concept of Holocaust was not the primary expression used by Wise to describe the bitter fate of Europe's Jews, but was one of a number of terms he used to explain what was occurring in the death camps of Eastern Europe. ${ }^{97}$

The information that flowed to the WJC offices was instrumental in exposing the dimensions of the murder of European Jewry, but its importance went further than that. The factual evidence collected by Congress branches in Europe was new, more detailed, and more extensive than earlier data. Consequently, the raw material and its interpretation by the WJC leadership have been of pivotal importance in shaping Holocaust memory from the 1940s to this day. A prime example of this is the October 1942 report on the condition of Polish Jews, which provides dramatic details of the murder of hundreds of thousands and the use of gas as a means of murder. The authors relate further that the corpses of the murdered Jews provided raw material for the manufacture of soap. This was the first mention of Jewish corpses being used for the manufacture of soap. ${ }^{98}$ We may assume that any report dispatched to the head office in New York from the Congress office in Geneva would come into Stephen Wise's hands. Several weeks later, in the November 26, 1942, edition of the New York Times, Wise wrote regarding the use by the Germans of Jewish corpses to manufacture soap. This announcement by Wise marks the beginning of the trans-

93 Guggenheim's testimony, October 29, 1942, AJA, 361 A8/11.

94 Telegram on the fate of Polish Jewry, December 1, 1942.

95 The Geneva report, October 8, 1942, AJA, 361 H287/12. Also, Document on Treblinka and Warsaw Ghetto, September, 1943. On the discourse about the concepts of Holocaust and genocide and their presence in history, see Frank Chalk and Kurt Jonassohn, Genocide Analyses and Case Studies (New Haven and London, 1990), 323-377.

96 Wise's address to the American Jewish Convention in New York, August 29, 1943, AJA, 361 A2/3.

97 For a comprehensive discussion of the evolution of the concept Holocaust, see Uriel Tal, "On the Study of the Holocaust and Genocide" [in Hebrew], Yad Vashem, Collection of Studies 13 (1980): 43-47. For discussion of the concept of Holocaust in the American arena, see Hasia R. Diner, We Remember With Reverence and Love (New York, 2009), 21-22, 382-383.

98 The Geneva Report, October 8, 1942, AJA, 361 H287/12. 
formation of the report's content into an issue that gained a significant foothold in public memory and has continued to resonate among scholars to this day. ${ }^{99}$

There is general consensus among Holocaust scholars that while isolated attempts to manufacture soap from Jewish corpses may have been made, the Germans did not conduct an industrial manufacturing process of this kind. The soap story constituted but one element of the accurate information collected by WJC functionaries during 1942. It was possibly the difficulty of coming to terms with the tragic condition of Europe's Jews in 1942 that led Wise and later generations to use the topic to bring home to the public the fact that the process of extermination of European Jewry could not be grasped in relation to any familiar human norm.

A further issue that emerged from the reports on events in Europe is the manner in which the documents' authors addressed the topic of Jewish resistance. In their interpretation of the material pertaining to Treblinka extermination camp, the anonymous author or authors expressed surprise at the fact that the young people in the camp, particularly the prison laborers, had utterly failed to resist the Germans' actions. This criticism was voiced in spite of the various editors' above-mentioned caveat that a large part of the testimony had emanated from Polish rather than Jewish sources, and that these sources had deliberately sought to emphasize the passivity of the Jewish response to the horrendous acts perpetrated by the Nazis. Particular attention was drawn to a description of the murder of 500 Jewish prisoners who served in the camp's labor force. The slaughter took place in early September; the victims were shot one after another, the first at seven thirty in the morning and the last at three thirty in the afternoon. The report's authors stressed that although the 500 victims were young and were murdered in succession over a period of many hours-which ostensibly had allowed them the opportunity to resist-not one of them had lifted a hand against the murderers. Despite its critical view, the report makes clear that the prolonged famine and emotional attrition at the hands of the Germans had caused the Jews to lose their capacity for resistance. All they desired was to ensure that their deaths came quickly and smoothly and that they be spared additional suffering.

The report's authors viewed the failure of the thousands of Jews who arrived by train to resist their murder in a similar vein. Here too they underscored the Jews' physical and emotional exhaustion and furnished additional details of the Germans' strategy of deception, including the posting of signs displaying trades such as tailor and shoemaker so as to create the impression that the selection

99 For discussion of the issue of use of Jewish corpses for the manufacture of soap, see Joachim Neander, “The Danzig Soap Case: Facts and Legends around 'Professor Spanner' and the Danzig Anatomic Institute 1944-1945,” German Studies Review 29, no. 1 (2006): 63-86. 
process was intended to form groups that would work for the Germans. It is somewhat ironic that the early criticism of the Jews' behavior in the extermination camps was aimed at the inmates of the Treblinka camp; in the latter stages of the war, a well-organized underground operating there would mount an impressive and heroic uprising that led to the cessation of the camp's extermination process.

In contrast to their criticism of the behavior patterns of the Jews imprisoned at Treblinka, the authors wrote with great admiration of the Jewish uprising in the Warsaw Ghetto. Despite the meager source material at their disposal, the authors devoted considerable space to a description of the revolt, adding their interpretation of the Jewish acts of heroism toward the end of the document: "A Jewish fighting organization led the defense in the ghetto. Their forces were small, they did not have much ammunition. Nevertheless they fought for four weeks with more effort than the Germans in this tragic struggle." 100 Thus, as early as 1943 a singular mix evolved containing criticism of the Jews' acceptance of their fate on the one hand, and glorification of Jewish resistance, particularly in the Warsaw Ghetto, on the other. This emphasis on the significance of the Jewish resistance in Warsaw Ghetto in the 1943 report heralded a concerted effort on the part of the WJC leadership to enhance the role of the Warsaw Ghetto uprising in the Holocaust memory that they sought to shape. As will be revealed in subsequent chapters, the leaders furthered this objective through the organization's publications by preparing study programs on the uprising, and by organizing memorial events in which the uprising played a major role. ${ }^{101}$

The authors of the WJC documents produced in 1942 and 1943 leveled criticism at the manner in which the Jews at Treblinka comported themselves, but refrained from commenting on the Judenrat (council of Jews responsible for implementing Nazi policies within their communities) in the Warsaw Ghetto or the kapos at Treblinka. The special status of the kapos in the camp was mentioned, along with the attendant benefits, but no value judgment was made. The activities of the Judenrat in the Warsaw Ghetto were addressed in a similar vein. The authors merely provided a general description of its activity and wrote of its role in the transport of Jews from the Ghetto, without criticizing its members in any way. They underscored the fact that its activity was conducted according to the Germans' demands. This approach differs considerably from the historical and public discourse conducted during the initial post-Holocaust decades, in

100 Report, September 1943 (no precise date or author given), AJA, 361 H294/2.

101 See the Congress's collection of documents and publications on the topic of the uprising produced in the 1950s, AJA, $361 \mathrm{H} 294 / 2$. This issue is extensively addressed in later chapters in the context of the WJC's role in shaping Holocaust memory in the United States. 
which trenchant criticism was leveled at the Jewish councils, and occasionally led to indictment of individuals who had acted as kapos.

Discussion of the shaping of Holocaust memory both in general and in the context of collaboration between Jews and Nazis goes beyond the scope of this book. One may assume that the work of scholars and intellectuals such as Hannah Arendt contributed to the emergence of a critical discourse on patterns of cooperation between Jews and Nazis during World War II, at the final stages of the war, and thereafter. The WJC documents clearly show that so such discourse was conducted when the reports from Europe began to arrive. ${ }^{102}$

\section{The World Jewish Congress Leadership and the Jewish Public in the United States at the Time of the Holocaust}

The tragic news conveyed by the WJC's European bureaus to the New York headquarters shaped the perception of the organization's leadership with regard to the destiny of Europe's Jews. This new perception stems from an April 1943 letter from Nahum Goldmann to Yitzhak Gruenbaum, a member of the Jewish Agency executive and chairman of the Rescue Committee, who was based in Palestine. ${ }^{103}$ This letter, which has not attracted the attention of scholarship until recently, reveals cardinal aspects of the issues under discussion.

Goldmann notes that the purpose of the letter was to report on the situation in the United States with regard to activity pertaining to European Jews, and especially on the WJC's efforts concerning this matter. He describes how the initial reports of the murder of Jews by the Germans had been received from WJC representatives in Europe, how officials at American delegations to neutral countries had verified them, and the manner in which the information had been made public in coordination with the U.S. State Department. Upon receipt of the news, the WJC became the driving force in launching varied and intensive action

102 For a discussion of the role of the concept "Like lambs to the slaughter" in the United States, see Feingold, Bearing Witness, 41-53. Among the prominent studies that sparked debate about the Holocaust in general and the patterns of collaboration of Jews with the Germans in particular, see Raul Hilberg, The Destruction of the European Jews (Chicago, 1961). For an extensive discussion of similar contexts of Holocaust memory in Israel, see Hanna Yablonka, "The Development of Holocaust Consciousness in Israel: The Nuremberg, Kapos, Kastner and Eichmann Trials," Israel Studies 8 (2003): 1-24. For a prime example of critical writing in the United States regarding the behavior of the Jewish public in general and of the Jewish leadership in particular at the time of the Holocaust, see Hannah Arendt, Eichmann in Jerusalem. A Report on the Banality of Evil (New York, 1963).

103 Letter from Goldmann to Gruenbaum, April 5, 1943, CZA, Z-6/2755. 
designed to arouse public opinion and to persuade Washington to take more concerted action toward rescuing Jews and assisting those Jewish refugees who had managed to flee from Europe. This activity, according to the letter, had come to a head in a mass rally held in March 1943 at Madison Square Garden in New York. Yet despite this impressive volume of public activity, Goldmann concludes by stating that the practical achievements of the WJC on behalf of European Jewry had been meager. He describes the sympathy expressed by senior state department officials toward the plight of Europe's Jews-in contrast to the apathy exhibited by Britain's Foreign Minister Anthony Eden-but adds that he and the Congress leaders were convinced that the U.S. State Department would take no practical action to assist European Jewry, verbal support of its leaders notwithstanding. Goldmann explains that this state of affairs was manifested when the Bermuda Conference turned out to be a meaningless event. (The conference was convened in April 1943 and was attended by delegates from Great Britain and the United States-ostensibly to discuss the problem of all World War II refugees, but in fact to address the Jewish issue.) He particularly underscored the Allied leaders' unwillingness even to consider implementation of his plan, the principal element of which was the issuing of a formal request by the Allies to Germany to allow Jews to leave the areas under German occupation, together with an offer to provide food for the Jews of Europe on condition that the mass murder ceased. ${ }^{104}$

Goldmann himself was thus well aware that the Congress's efforts to rescue the Jews of Europe would come to nothing; as his letter to Gruenbaum demonstrates, this conclusion did not stem from some transitory frustration at the failure of the rescue effort, but rather from a profound analysis of the American political arena. This is evident from a previous letter that Goldmann sent to Myron Taylor, a State Department official and chairman of the Inter-Governmental Commission on Refugees. In it Goldmann collated detailed information from Europe that had been forwarded to the State Department pertaining to the mass murder of Polish Jews and the expansion of the Germans' murderous deeds to additional areas of Europe. This information had clearly failed to spur the Roosevelt Administration into taking effective action, and Goldmann believed that this state of affairs would not change. ${ }^{105}$

While he was fully aware that they had failed to assist European Jews, Goldmann made it clear to Gruenbaum that this had not incited WJC functionaries to initiate more radical public action, nor to attempt to increase public pressure on President Roosevelt's administration to act. They had adopted this less aggressive approach because they knew that their limited public power in the American

104 Ibid. On Goldmann's plan, see Wyman, Abandonment of the Jews, 187-188.

105 Goldmann's Letter to Myron Taylor, March 24, 1943, CZA, Z-6/2755. 
arena and the obstacles presented by the reality of a world war made it exceedingly difficult for them to influence administration policy concerning the Jewish cause. They believed that the only success that the organization had achieved on behalf of the Jews had come from clandestine diplomatic activity on the margins of events, such as preventing the expulsion of Jewish refugees from Spain, rather than from open public action. Goldmann stressed the futility of dispatching Zionist leaders from Palestine to the United States in order to increase pressure on the administration. ${ }^{106}$ He ended the letter on a painful note, saying that one must assume that the majority of Jews living in the areas of Nazi occupation would be exterminated. He was aware of the gravity of his words, stressing that this was a harsh diagnosis but that any other conclusion would be tantamount to disregarding the facts. ${ }^{107}$

Goldmann's words merely serve to exacerbate questions about the tendency of WJC functionaries to moderate their overt public and political activity on behalf of European Jews, and even to take measures to restrain American Jewish activity. They chose this path despite being fully aware of the fate of European Jewry-even though vigorous public action on behalf of Jewish groups throughout the world had formed a major element of their public platform throughout the thirties and forties. The disparity between Goldmann's overt and covert activity became apparent several months later. In August 1943 he delivered one of the main speeches at a conference of the American Jewish Congress, which had assembled at the Waldorf Astoria Hotel in New York. His speech addressed events in Europe, but presented a more optimistic prognosis regarding the fate of European Jewry. While in his classified letter to Gruenbaum he had predicted that the great majority of Europe's Jews would be murdered by the Nazis, in his public speech to the conference he asserted that millions of European Jews would survive the horrors of the war. Goldmann continued in this optimistic tone even so far as to entertain the possibility that a significant number of Jews would be able to return to Warsaw, Cracow, Vilnius and other cities of Eastern Europe after the war. He then enumerated the complications involved in the process of return, and emphasized the social and spiritual aspects associated with rehabilitation. ${ }^{108}$

106 A similar survey of the rescue efforts in the United States as well as the conclusion that it was impossible to achieve more and the conviction that there was no need to dispatch Zionist leaders from Palestine to the United States may be found in an earlier and less detailed letter from Goldmann to Eliezer Kaplan, a member of the Zionist executive and Treasurer of the Jewish Agency. See Goldmann's letter to Kaplan, January 11, 1943, CZA, Z-6/2755.

107 Goldmann Letter, to Gruenbaum, April 5, 1943, CZA, Z-6/2755.

108 Goldmann's speech to the American Jewish Congress, New York, August 30, 1943, AJA, 361 A2/3. 
A possible explanation of the WJC's restraint is to be found in the relationship between the Congress leadership and that of another body, the American Jewish Committee, which represented the American-Jewish elite of German origin. In his letter to Gruenbaum, Goldmann portrayed the American Jewish Committee and particularly its president, the jurist Joseph Proskauer, as having consistently opposed any attempt to take more radical action on behalf of Europe's Jews, and cited their firm opposition to intensifying the public campaign on this issue. ${ }^{109}$ Despite this portrayal, which suggests that WJC functionaries were overtly attempting to lay part of the responsibility for the lack of action on the Committee-going so far as to portray the American Jewish Committee as bearing most of the blame for the failure of the campaign to generate significant public pressure on the administration-we learn from Goldmann that the two organizations had worked in close cooperation and coordination. They both sought to moderate the public activity of the American Jewish community. ${ }^{110}$ This matter is particularly noteworthy because in his memoirs, Goldmann goes to great lengths to show that the WJC took political and public action to counteract the Jewish elites of the kind represented by the Committee, emphasizing the need to democratize Jewish life in the United States and to oppose the Jewish philanthropists. He goes on to note that economic struggle against the philanthropic foundations was one of the Congress's objectives, thereby justifying its independent existence, especially its fundraising machinery. ${ }^{111}$

It is worth noting that this disparity between the public stance of the founders of the WJC regarding their objectives in establishing the body and their practical activity also became evident during the preparations for founding the organization and its actual establishment in Europe between 1932 and 1934. The publicly pronounced desire to create a democratic organization in Europe that would not discriminate between Eastern- and Western-European Jews clashed with opposing trends arising from the practical need to mobilize the Jewish elites of Western Europe and North America toward activity within the WJC, because those cohorts possessed the financial and political resources that could provide the WJC public power and financial stability. Stephen Wise, Louis Lipsky and Nahum Goldmann thus made a point of ensuring that the Congress's convention in Geneva in 1936

109 Ibid. Discussion of the activities of the American Jewish Committee during World War II goes beyond the scope of this book. I have merely quoted Goldmann on this matter, and have not taken a stand on this complex issue. For an extensive discussion of this topic, see Naomi W. Cohen, Not Free To Desist: The American Jewish Committee 1906-1966 (Philadelphia, 1972), 227-264 (hereafter: Chen, The American Jewish Committee).

110 On the cooperation between Wise and Proskauer, see Cohen, The American Jewish Committee, 244-245.

111 Goldmann, Autobiography, 195-196. 
would be relevant above all to the Jews of the Western world. They regarded this as a supreme goal, citing the need to reinforce the impression of the dominance of Western Jewry in the WJC, and to guard against an Eastern-European atmosphere from prevailing at the convention. In order to achieve this, they meticulously sought to arrange the opening session in such a way that the majority of speakers would be Western Jews. Sessions were, whenever possible, to be conducted in English, and the addresses were to be short and to the point-in keeping with their perception of the American style. ${ }^{112}$

Thus, Goldmann's criticism of the American Jewish Committee appears to contradict the cooperation that he described in the letter. In fact, the two organizations worked together far more closely than can be inferred from the letter to Gruenbaum - and far beyond the extent required either to present a united Jewish front or to leverage the political connections and personal stature of the heads of the Committee.

A desire to conceal the political cooperation between Goldmann and Proskauer, who belonged to manifestly competing organizations, is likewise evident during the latter half of the 1940s. The political coordination between the two men in preparation for Goldmann's mission to Washington in summer 1946 as a representative of the Jewish Agency, which had convened in Paris, was close and ongoing. Nevertheless, Goldmann impressed upon Proskauer the need to keep their relationship a secret and to refrain from mentioning it in public. ${ }^{113}$

There is further evidence of the way in which Wise, Goldmann and Proskauer coordinated their political and public activities. There are records of discussions among the three men regarding a press conference scheduled for April 1943. The hope was that describing the dire plight of Europe's Jews and condemning the Roosevelt administration's inactivity on the issue would spur the administration into more concerted action on their behalf. On April 22, 1943, Wise reported to Goldmann on a conversation he had held with Proskauer some days earlier, in which the two had concluded that the planned press conference should be canceled. ${ }^{114}$ Not only did Wise believe that the press conference would be of no

112 Louis Lipsky documents, Archive of the American Jewish Historical Society, New York, collection P-672, box 3. File 5 (hereafter P-672 3/5).

113 Goldmann's letter to Proskauer, June 28, 1946, CZA, Z-6/69. On testimonies regarding further clandestine meetings attended by Goldmann and Proskauer, see letter from Emanuel Neumann, an American Zionist functionary and assistant to Abba Hillel Silver, to Louis Lipsky, August 30, 1946, CZA, A-123/120.

114 Wise's letter to Goldmann, April 22, 1943, CZA, Z-6/18. We may surmise that the press conference had been planned following the failure of the Bermuda Conference. In the end no press conference was convened by an official Jewish or Zionist body to protest the failure of the Bermuda Conference. 
benefit to the struggle, but he feared that it might undermine it. It would not motivate the United States Congress to exert pressure on Roosevelt. On the contrary, Wise foresaw that in the public debate that the press conference would kindle, the president would for the first time win the support of the generally hostile Congress. He felt that Congress was, on the whole, anti-Semitic, and could thus be expected to support Roosevelt if he were to be accused of failure to support the Jews of Europe. Wise stressed that while a press conference could easily be convened and public meetings held, one must take into account their possible repercussions. He believed that such action would result in the closing of doors that remained open to Jewish activists, and that it was unrealistic to expect any help from Roosevelt in the rescue of Jews. Such public action would, he thought, be counterproductive, since as long as pressure was being exerted clandestinely rather than in the form of public press conferences, Roosevelt, who admittedly had yet to respond adequately to the murder of the Jewish people in Europe, would nevertheless remain a friend who had and would continue to do everything in his power for the sake of rescuing Jews. ${ }^{115}$

The letters reveal the bind in which Wise and Goldmann found themselves. They were both aware that the administration had not made an effort to undertake any rescue activity, but believed that this was due to structural constraints within the American political system in the first half of the 1940s. These constraints, so they thought, necessitated coordination with the administration with regard to the nature of public action taken in the United States to promote the rescue of Jews. ${ }^{116}$ Wise and Goldmann thought it advisable to blur Roosevelt's engagement with the Jewish issue in order to minimize his exposure to political pressures from his many adversaries in Congress, whom, as mentioned, they perceived to be anti-Semites who sought to denigrate the president by portraying him as a friend of the Jews-or even as someone who was prosecuting the war in response to Jewish pressure rather than in concern for American interests. Wise and Goldmann further believed that public criticism of Roosevelt's lack of action to save European Jews would harm him in another respect: He and his party's candidates were likely to lose their Jewish support as a result, which could

115 Wise's letter to Goldmann, April 22, 1943, CZA Z-6/18. For a similar opinion expressed by Wise concerning the nature of Roosevelt's activity on the Jewish issue, see a later letter to Goldmann. Wise expected that Roosevelt would not alter his approach to rescuing the Jews of Europe, and that they could do no more to promote the campaign for rescue in the United States. Wise's letter to Goldmann, July 27, 1943, CZA, A-243/24. Roosevelt's close advisor and speech writer has written about the considerable store he set on his stature in Congress and of his apprehension at the difficulties awaiting him in this political arena. See Samuel and Dorothy Rosenman, Presidential Style (New York, 1976), 346-347.

116 See, for example, the letter from Wise to Goldmann, September 4, 1942, CZA, A-243/124. 
restrict his political leeway. Goldmann, Wise and Proskauer thought that such a development would endanger the United States as well as world Jewry. ${ }^{117}$ Thus, in the official correspondence they conducted with a broad range of people, Wise and Goldmann presented an optimistic view with regard to the president's and the State Department's commitment toward European Jewry. Their predictions that the president would take no more than limited action appeared only in confidential correspondence, with a view to dampening the Jewish campaign against the president. ${ }^{118}$

Wise's view that it was essential to downplay the issue of the fate of European Jewry in the context of World War II, especially his desire to mitigate criticism leveled at the administration's actions regarding rescue, is further manifested in his address to the American Jewish Congress in late August 1943. Wise chose to begin his speech with a declaration that this was an American convention, explaining to his audience that the central component of their identity was their Americanism, and that they could be defined only as Americans rather than according to some other component linked to their religion or race: "This is an American Conference. We are American, first, last and all the time." 119 Wise continued by declaring that American Jews in 1943 shared the common goal of all American citizens, namely victory in the war against fascism. Defeat would mean that there would be no future. Throughout his entire address, Wise interlaced the dominant theme that an American victory in the war was the primary objective of all Jews and particularly of American Jews, thereby creating a clear link between victory in the war and the rescue of European Jews. ${ }^{120}$

117 For a clear example of Wise's world view as an American, and of his belief that the American democracy constituted the sole means whereby to rescue the Jews of the world and to defeat Hitler, see Wise's speech to the American Jewish Congress convention, February 11, 1940, CZA, A-243/71.

118 In addition to their critical comments toward the president's policy presented here, Wise and Goldmann uttered positive assessments of his actions and those of the administration. See Wise's report on his contacts with Roosevelt, addressed to Goldmann and to the heads of Jewish organizations, September 14, 1942, CZA, A-243/173; Goldmann's speech to the first assembly of the World Jewish Congress following the outbreak of war, November 1944 (no precise date), CZA, Z-6/2248. The policy of restraint in general, and the cooperation with the Jewish elites are of particular interest in light of Wise's prior propensity to wage bitter campaigns against these same elites. Discussion of this issue is beyond the scope of this book. Suffice it to say that the change in Wise's policy may have been due to a combination of factors linked to the singular circumstances that prevailed during the 1940s and to the fact that he had become a Jewish leader well connected to the Democratic establishment. On Wise's struggle against New York's Jewish elites, see Louis Lipsky, Zionist Figures [in Hebrew] (Jerusalem, 1957), 132-140

119 Wise's address to the American Jewish Congress, New York, August 29, 1943, AJA, 361 A2/3. 120 Ibid. 
Wise stressed that the goal of the Jewish Congress in August 1943 should be to protect and defend the United States, and as a corollary, also to protect and defend the Jewish people. He portrayed the close connection between victory in the war and the rescue of Europe's Jews as a consequence of President Roosevelt's leadership during World War II. Wise praised Roosevelt's integrity and his humanist outlook, proclaiming that the convention delegates unanimously supported the Commander in Chief (as he referred to Roosevelt in his speech) and his commitment to enhancing efforts at saving Europe's Jews. He went on to bemoan the difficulties that European Jews had encountered as they sought to migrate prior to 1939, emphasizing that unless the rescue efforts gained momentum there would be no one left to save. ${ }^{121}$

By underscoring the "Americanism" of Jews in the United States and equating the issue of the rescue of Jews with an American victory in the war, Wise sought to downplay the presence of the Jewish issue in the public arena. If his theses were accepted, there would be no need to undertake more intensive independent Jewish activity to press for the rescue of European Jews. His underscoring of the expectation that the administration would take more decisive action to rescue Jews was a calculated move and offered the only hint of his dissatisfaction with Roosevelt's insufficiently resolute action to promote the rescue of Jews. By virtue of his status as president of the WJC and his links to senior figures in the Roosevelt administration, Wise was aware of both the dimensions of the murder of Europe's Jews and the administration's feeble efforts with regard to their rescue. He merely alluded to criticism of the administration's activity on this issue and failed to call for concerted action to be taken. This position should be understood in light of his arguments against clashing with the Roosevelt administration, as manifested in the affair of the press conference that failed to convene in April 1943. Yet Wise nevertheless chose to imply criticism of the administration in an attempt to prompt it to take action and in order to respond to criticism on the part of American Jews leveled at the futility of rescue activities. ${ }^{122}$

121 Ibid.

122 Wise was well aware of the popularity enjoyed among the American Jewish community by militant associations such as the Bergson group, which sought to intensify public activity in the American arena to promote the rescue of Jews and to protest against the administration's inactivity on this issue. See Urofsky, Wise, 333-335. 